\title{
Participation in and responsibility for state injustices
}

Article

Accepted Version

Jubb, R. (2014) Participation in and responsibility for state injustices. Social Theory and Practice, 40 (1). pp. 51-72. ISSN 0037-802X doi:

https://doi.org/10.5840/soctheorpract20144013 Available at https://centaur.reading.ac.uk/43036/

It is advisable to refer to the publisher's version if you intend to cite from the work. See Guidance on citing.

To link to this article DOI: http://dx.doi.org/10.5840/soctheorpract20144013

Publisher: Florida State University Department of Philosophy

All outputs in CentAUR are protected by Intellectual Property Rights law, including copyright law. Copyright and IPR is retained by the creators or other copyright holders. Terms and conditions for use of this material are defined in the End User Agreement.

\section{www.reading.ac.uk/centaur}

\section{CentAUR}

Central Archive at the University of Reading

Reading's research outputs online 


\section{Participation in and Responsibility for State Injustices ${ }^{1}$}

\section{Introduction}

As political theorists and philosophers have become increasingly aware of collective acts and agents over the past decade or so, they have become increasingly interested in the question of what responsibility individual members of these collectives have for what the collectives have done. If our involvement in "the imposition... of a coercive global order that perpetuates severe poverty for many who cannot resist this imposition" makes us responsible for that poverty, as Thomas Pogge claims, this is because of the character of that involvement. ${ }^{2}$ We are responsible for the harmfulness of that order because our support for it is analogous to the support citizens of Nazi Germany provided to that regime, and so we are responsible for its results just as they were. ${ }^{3}$ Pogge's claim depends on the state-citizen relation being relevantly similar to the relation between the global order and its members. If citizenship is in some way distinctive, this could break the analogy between citizens of Nazi Germany and members of the current global order he sometimes relies on. For example, citizenship might ground special responsibilities to those with whom we share it. Indeed, cosmopolitan claims like Pogge's have been resisted in precisely that way. Andrea Sangiovanni, for example, has argued that citizens' reciprocal provision of "the basic conditions and guarantees necessary to develop and act on a plan of life" limit the responsibilities we have for those we do not share a state with. ${ }^{4}$

\footnotetext{
1 The paper was written whilst a Leverhulme Early Career Fellow at UCL, and I would like to thank both the Leverhulme Trust and UCL for their support. I also owe thanks to Justitia Amplificata, Centre for Advanced Studies, Goethe University, Frankfurt and the Forschungskolleg Humanwissenschaften in Bad Homburg where I was a visiting fellow during the time spent working on this paper. I incurred further debts of gratitude to all the following, who were generous enough to provide helpful comments on the paper or its ancestors: Sara Amighetti, Guy Aitchison-Cornish, Gabriele Badano, Ayelet Banai, Barbara Buckinx, Julian Culp, Lior Erez, Juan Espíndola, Rainer Forst, Stefan Gosepath, Burke Hendrix, Mattias Iser, Anja Karnein, Alex Leveringhaus, Nick Martin, Frank Nullmeier, Kieran Oberman, Avia Pasternak, Thomas Porter, Miriam Ronzoni, Christian Schemmel, Kathryn Schwarz, Anna Stilz, Christine Straehle, Patrick Tomlin, Jesse Tomalty, Laura Valentini, Peter Verovšek, Albert Weale, and Alexa Zellentin. Finally, I would like to thank the reviewers and all those involved with the submission process at Social Theory and Practice. The paper was substantially improved by their hard work.

2 Thomas Pogge (2002), World Poverty and Human Rights, Cambridge: Polity Press, pg. 23.

3 See for example World Poverty and Human Rights, pg. 135.

4 Andrea Sangiovanni (2007), 'Global Justice, Reciprocity, and the State' Philosophy and Public Affairs, 35 (1), 3-39, pg. 20. In this sense, Sangiovanni's rationale for limited duties of egalitarian justice
} 
Here, I probe the nature and extent of citizens' responsibility for the structure and acts of the political order they share. If a state commits a rights-violation, when, if ever, do its citizens bear a particular responsibility for its wrong? ${ }^{5}$ We hold states responsible in international law knowing that the costs of doing so will be passed on to their citizens, who will often have had little choice about what their state has done. ${ }^{6}$ Equally, we also treat citizens as particularly responsible for some wrongs victimizing those they share their political institutions with. I take it as intuitive that British citizens have a special responsibility for their police force's institutional racism. ${ }^{7}$ They have duties to try and end the racist policies, to disown the acts and actors involved in them, and to make good the damage they inflicted that others lack. In David Miller's sense, citizens often have remedial responsibilities for their government's wrongs. ${ }^{8}$ Whether or not they are causally responsible for them, or can be praised or blamed for them, they must bear the costs of correcting them. Still, we do not always hold citizens responsible for what their governments do in that way. Sometimes, as for instance in the case of the sale of public honours, the wrongs of state officials or institutions do not seem to be the responsibility of citizens in general. Duties to apologise to or compensate those who lost out fall on those

distinguishes Nazi Germany, which provided such an order, from the current global order, which he claims does not.

${ }^{5}$ Strictly, the rationale I give in the paper does not apply to citizens, but legal residents. Citizens who live abroad are not participants in the construction of a political order, while someone who structures their life around its availability is. However, this elision is standard in the literature. See for example, Anna Stilz, (2010) 'Collective Responsibility and the State', Journal of Political Philosophy, 19 (2):190208, pg. 190, where she describes her focus as being on "the distribution of state responsibility to citizens", and then immediately rephrases that involving passing "responsibility on to its members" and a "tax burden" on "individuals". Being a citizen is not necessary or sufficient for bearing a tax burden - or for having one's basic rights protected by a given state, Stilz's rationale for the transfer of responsibility.

6 See Collective Responsibility for the State, pg. 190.

7 Official British police statistics show that a black person was seven times more likely to be stopped and searched by the British police than a white person in 2009-10. See Vikram Dodd, 'How Steven Lawrence and his Family Jolted a Nation's Conscience', The Guardian, 03/01/2012. http://www.guardian.co.uk/uk/2012/jan/03/stephen-lawrence-jolted-nationconscience?intcmp=239, last retrieved, 14/02/2012. Of course, other relationships to the British police may ground more extensive responsibilities than are borne simply because one is a citizen. 8 See David Miller (2007), National Responsibility and Global Justice, Oxford: Oxford University Press, pp. $81 \mathrm{ff}$, for what he means by remedial responsibility. Stilz calls more or less the same kind of responsibility 'task-responsibility', while Avia Pasternak refers to it as 'liability-responsibility'. See Collective Responsibility and the State, pp. 194-195 and Avia Pasternak, (2012), 'Limiting States' Corporate Responsibility', Journal of Political Philosophy, DOI: 10.1111/j.1467-9760.2012.00423.x, pg. 3 . This is the kind of responsibility I am concerned with here, and I make no claims about other kinds of responsibility, particularly the responsibility all three of those authors distinguish the responsibility they are interested in from, the responsibility that justifies praise and blame. 
involved in the sales, not the population at large. There is then a question about when a state's elite should be treated as "a private band of conspirators" the costs of whose wrongs citizens lack any special responsibility for. ${ }^{9}$

Various accounts of how to think about citizens' responsibility have been put forward in the literature, none of which seem entirely satisfactory to me. One problem is the character of citizens' relationship to the state. That relation is typically non-voluntary and profoundly shaping for citizens, who enjoy a stable background against which to plan and live their lives because of it. These features need to be taken into account by any theory of citizens' responsibility. Theories which do not take proper account of the pervasive, massive coercive power of the state will fail. However, that feature of the state will need to be integrated into the theory in the right way. I will try to show that existing 'political' accounts fail because they cannot select amongst our plausible judgments about citizens' responsibility in a way that draws them satisfactorily under a unifying rationale.

The rest of the paper is structured as follows. First, I outline the challenges any account of citizens' responsibility faces because of the way political orders create the background conditions for widespread consensual and mutually beneficial interactions. I focus on accounts of citizens' responsibility for confronting and remedying injustices their states commit which base that responsibility on having benefitted from or endorsed the injustice. They fail because of their indifference to the particularities of the state-citizen relation. This justifies screening out accounts which are similarly indifferent, and allows me to move on to discuss four cases. I use these to test the plausibility of the unifying rationale provided by appropriately political accounts of citizens' responsibility. We already see citizens as responsible for what their state does in various ways. Even if our favoured account ends up condemning our pre-reflective practices of accountability, it must engage with them. Unless an account can explain where, how and why they have gone wrong, it will seem like an answer to another problem, a problem we would have if we thought of ourselves and our relation to the state differently.

Here, I suggest that thinking of the state as authorized by citizens to provide a political order may also be problematic. The prominent version of such an account recently provided

9 Collective Responsibility and the State, pg. 197. 
by Anna Stilz has two difficulties I draw out using my four cases. First, we judge citizens of some autocratic states responsible that it denies are responsible and second, it does not draw a seemingly important distinctions between public and private acts of state officials. Of course, it is not enough simply to show that an account of some normative concept like responsibility generates implausible judgments in its field of application. It is important to also have an explanation of the error. Otherwise we cannot be sure that it really is an error, or how we should avoid and improve on it. In the third section, then, I discuss where I think using the idea of authorization to explain citizens' responsibility goes wrong. I argue that using the idea of authorization to characterise the state-citizen relation over-extends the concept, which anyway has too few resources to differentiate between the public and private acts of the state and its agents. Distinguishing between the state's private and public acts is crucial to being able to cover the four cases I outline. The alternative rubric of participation makes this possible by focusing on the question of involvement. Citizens participate in state acts when they are involved in and so play a role in them. They play a role in an act or a project when their intentional action depends on and supports the goals and constraints associated with that act or project. When state acts or projects are in the relevant sense private, citizens' acts will not incorporate its goals and constraints in this way. On that basis, I suggest that participation is a superior way of thinking about citizens' responsibility for state wrongs.

\section{The State as a Provider of Order}

Let us begin by considering accounts of citizens' responsibility based on endorsement of the state and its ends, or on having benefitted from its activities. Avia Pasternak and David Miller both have something like an endorsement account of citizen responsibility. As Pasternak sees it, the strength of her view is that it makes responsibility depend on “citizens' subjective perceptions of their citizenship status".10 Its 'objective' criteria are designed to "guarantee that individuals are able to reflect upon and assess their membership status".11 When respect for basic human rights gives them the option, citizens who do not "signal their resentment of their state" are responsible for what it does. ${ }^{12}$ Miller

10 Limiting States' Corporate Responsibility, pg. 13.

11 Limiting States' Corporate Responsibility, pg. 13.

12 Limiting States' Corporate Responsibility, pg. 15. Pasternak's reasons for making her view depend on what citizens think of their state seem mistaken. She takes it that citizens who resent their state 
has a similar 'like-minded' model of group responsibility. A member of a group who approves of its general ethos is responsible for what that group does, at least in line with its ethos. ${ }^{13}$ Whites living in the southern states of the USA in the Jim Crow era were responsible for the violent enforcement of racial hierarchies there simply in virtue of their views about the superiority of whites. Whether they participated in or approved of that violence is irrelevant. ${ }^{14}$ Alternatively, one of Daniel Butt's three grounds for responsibility for historical injustice is having benefitted from it. ${ }^{15}$ A criterion of benefit has also been used to ground the permissibility of affirmative action for women and ethnic minority job candidates. Such programmes take the benefits of injustice and return them to those originally entitled to them. ${ }^{16}$

I am sceptical about whether endorsement or benefit is enough to ground remedial responsibility for injustice in general. It seems that there are many cases where having benefitted from or endorsed a justice does not make you specially responsible for dealing with its consequences. Benefitting from the unjust exclusion or removal of a competitor does not mean being specially responsible for covering the costs of the wrong inflicted on them. Neither does hoping for or wanting it. Equally, many cases where benefit or endorsement appear relevant to responsibility can be redescribed so as to ground responsibility another way. It might seem I am responsible for returning stolen goods because I benefit from having bought them. However, perhaps I should remedy the wrong of theft because I treated someone who had no right to dispose of certain items of property as having such a right. After all, I should return the goods even if I was swindled by the thief

do not intentionally participate in it, glossing the fourth of her four criteria for participation (pg. 11) as involving dissatisfaction and resentment on pp. 14-15. This seems false. I can intend to do things I resent doing. She seems to believe this because this gives citizens control over their responsibilities (pg. 7). It is not clear though that we have very much control over what we resent, or that allowing some to avoid responsibility increases control over responsibilities in general. In particular, victims of wrongdoings might feel they had had responsibilities to meet their needs from their own resources rather thrust upon them.

13 See for example National Responsibility and Global Justice, pg. 117ff. Although Pasternak requires that individuals are members according to the group's own rules (pg. 9), it is not at all clear what would make someone a member on Miller's account.

14 National Responsibility and Global Justice, pg. 118.

15 See for example Daniel Butt (2008), Rectifying International Injustice, Oxford: Oxford University Press, pp. 97-133. His other two grounds are "possession of misappropriated property which belongs to others" and membership of "political communities which have failed to fulfil their rectificatory duties to non-nationals" (Rectifying International Injustice, pg. 195).

16 See for example George Sher (1975), 'Justifying Reverse Discrimination in Employment', Philosophy and Public Affairs, 4 (2): 159-170. 
and so did not benefit from the transaction. Set aside the issue of the general plausibility of endorsement or benefit as a ground for remedial responsibility for injustice though. My concern here is to show that they are not appropriately political.

Relying on either benefit or endorsement as a ground for remedial responsibility seems excluded by the relationship between state and citizen, and citizen and citizen. States provide political order so that individuals with different and often directly competing ends can live together in a minimally commodious way, without constantly coming into conflict with each other. ${ }^{17}$ They are not voluntary associations we join in order to gain some benefit or to pursue some shared end, but coercive institutions which make those kind of associations possible. Treating them as institutions we benefit from has at least two problems. First, there is the difficulty of who the supposed beneficiaries are. By solving what Bernard Williams thought of as 'the first political question', and securing "order, protection, safety, trust, and the conditions of cooperation", states create the environment we exist in and through it, us. ${ }^{18}$ Without the political institutions we grew up in and our families relied on for a stable environment, it is not clear who we would be at all. Who then are the supposed beneficiaries, and what is the benefit they have received? Second, assessment of benefits needs to be from a morally appropriate baseline. However, in the absence of a political order life infamously may be nasty, brutish, and short. Certainly, Butt's requirement that "all interaction between the relevant parties was just and consensual" would not be met, even if we knew what meeting it involved.19 Without a state goods like respect and reciprocity would be very difficult to achieve, but ignoring the way states provide order is not the basis for an accurate assessment of what they have done either.

For theories based on endorsement the problem is that, as Rawls put it, a state ought to be "neither a community nor an association".20 If what states do is provide order for actors whose different ends mean they would otherwise struggle to coordinate themselves, then

17 See for example Bernard Williams, (2005), 'Realism and Moralism in Political Theory', in Bernard Williams and Geoffrey Hawthorn (eds.), In the Beginning was the Deed: Realism and Moralism in Political Argument (Princeton: Princeton University Press), 1-17 or John Rawls (2001), Justice as Fairness: A Restatement, Erin Kelly (ed.), Cambridge: Harvard University Press, pp. 1-5.

18 Realism and Moral in Political Theory, pg. 3.

19 Rectifying International Injustice, pg. 115.

20 Political Liberalism, pg. 40. 
states should, in a certain sense, lack ends. ${ }^{21}$ At least, if they do not, we cannot expect all their citizens to share them. Perhaps the responsibility of the members of the private associations for the pursuit of shared ends like churches or clubs that the state makes possible can be grounded in endorsement of those ends. Citizens' responsibility could not be grounded in that way though.

Benefit and endorsement both fail to recognise the special features of the case of states and their citizens' responsibility for their acts. It is clear then that we need some alternative account of how the transfer of responsibility from a state to its citizens occurs, an account which grasps the sort of institution a state is. Instead of relying on principles which treat the state as if it were some kind of voluntaristic joint venture, we should base citizens' responsibility for what it does on the way it authoritatively provides an order for them. Without such an authority, human life will considerably less cooperative and probably also significantly more violent. What we might call the objective conditions of agency for human beings would be absent.

One way we could understand the state as providing a guarantee of order is to see citizens not as benefiting from or endorsing it, but rather as authorizing it. Citizens have rights to the objective conditions of agency, after all, but face various coordination problems in enforcing and realising them. When the state fulfils its role as the protector of citizens' ability to live a life that is not nasty, brutish and short, it enforces those rights. Because it is the vehicle through which they must make their claims on one another to those conditions, citizens could be seen as owning and so authorizing the acts of the state. Although there are a number of theorists in the history of political thought who may have claimed that citizens authorized their state, here I focus on Anna Stilz's recent claim that they authorize it and are responsible for it in virtue of that authorization. ${ }^{22}$

\footnotetext{
21 Miller's discussion of endorsement as a criterion for responsibility is actually aimed at nations rather than states. See for example, National Responsibility and Global Justice, pp. 111. These may be more like associations for the pursuit of shared ends than states, although it is not clear how, in the absence of state-like institutions it controls, with all the constraints that implies, a nation might act. 22 See Collective Responsibility and the State. Although John M. Parrish has also invoked the idea of authorization through rights protection (see his (2009), 'Collective Responsibility and the State', International Theory 1 (1): 119-154), Stilz's view is clearer about when a state is authorized. She ascribes the authorization view to Hobbes, Rousseau, and Kant. See Collective Responsibility and the State, pg. 198.
} 
Since it begins with an appreciation of the role that states actually play, Stilz's account is political in the way that an account of citizens' responsibility for what their states do should be. In that respect at least, it is a superior account to alternatives based on benefit or endorsement. Unlike them, it appropriately confronts the basic structure of the problem it faces. However, meeting that criterion does not mean that it automatically produces the right answers, any more than any other view which did so would. Stilz's 'democratic authorization' view makes citizens responsible in some cases and not in others, since it is only when the state protects their basic rights that they authorize and so are responsible for it. They authorize it as long as "its laws qualify as a possible general will, by passing a minimal threshold for taking each citizen's interests into account".23 In order to do this, states must provide citizens with three things. ${ }^{24}$ First, citizens must have a basic set of liberties. Second, they must be granted equal status, both in terms of formal equality before the law and a guarantee of subsistence rights. Third, at least under contemporary political conditions, they must have democratic rights to participate in the law-making process. Under these conditions, citizens are responsible, in the sense of being liable for the costs, for their government's acts. Are these the set of conditions under which we think citizens should be held responsible for their government's acts though? By looking more closely at Stilz's account, we can see what additional or alternative conditions might apply to theories of when citizens are responsible for their government's wrongdoing.

\section{Responsibility and Democratic Legal States}

We ask questions about citizens' responsibility for what their states have done because the history of human political organization is often a history of dissatisfaction and moral failure. Because of that, there are questions about who is responsible for the costs of what our political institutions do that they should not have done. A theory based on authorization answers that citizens are liable when they authorize their state. We are justified in requiring citizens to bear the costs of remedying injustices committed by their state when it respects their basic rights. Where states do not respect basic rights, citizens may not be responsible in that way. ${ }^{25}$ If they are responsible, it will be for different reasons. Like any other, the answer to questions about citizens' responsibility provided by authorization theory must be

23 Collective Responsibility and the State, pg. 201.

24 Collective Responsibility and the State, pp. 202-203.

25 See Collective Responsibility and the State, pp. 197-198. 
sensitive to considered judgments about wrongs committed by governments or their agents and whether citizens are responsible. ${ }^{26}$ It must either match these judgments or have a satisfactory explanation of why. If it cannot explain why it demands we renounce our considered judgments, then we should seek alternative theories which do not have that weakness.

In this section, I discuss four historical cases of state wrongdoing and the judgments we make about citizens' responsibility in them. I suggest that we want to use two overlapping distinctions to judge whether citizens were responsible for what their state did in the cases. The first of these distinctions is between governments which rely on broad acquiescence to their claim to a right to rule and those whose position rests on near-absolute control over their population. The second distinction is between wrongs that involve citizens as such and wrongs which are in some way clandestine or private. Democratic authorization theory judges these cases only according to whether the state in question was a democratic legal state. It thus does not recognise the need for a distinction between clandestine and public wrongs, and uses a distinction between democratic legal states and all others rather than one between states which are nakedly coercive and those which are not. That failure to match our considered judgments about these cases weakens democratic authorization theory, as it would any other account of citizens' responsibility.27 It allows citizens to be held responsible for wrongs that are kept secret from them, while denying that citizens who cooperate with their regime can be responsible for it in virtue of that cooperation, even if it is not democratic.

If we consider, for example, contemporary North Korea, we can see that citizens in general cannot be held responsible for a state's wrongs simply because it is their state. North Korea is a nuclear-armed, hereditary totalitarian dictatorship with the fourth-largest military in the world, and has an extensive network of secret police and labour camps to ensure that

\footnotetext{
26 See Justice as Fairness: A Restatement, pp. 29-31 for an account of the role of considered judgments and reflective equilibrium.

27 Other existing theories also struggle. For example, Pasternak's theory cannot account for these four cases and our considered judgments about them as well. This is because in the end it relies on a state's respect for human rights as a criterion for holding citizens responsible, at least if they do not signal their resentment. See for example Limiting States' Corporate Responsibility, pg. 11ff. Consequently, it cannot pick out nakedly coercive regimes, since many regimes which violate human rights do not depend on brute force to rule over the bulk of their population. Nor can it distinguish wrongs which are secret from those which are public.
} 
the population live within extremely strictly regimented lines. During the 1990s as Cold War-era aid was cut off, it suffered a famine in which up to $10 \%$ of the population starved to death. Yet the party elite remained dominant. ${ }^{28}$ A defector living in South Korea reportedly "marvelled that George Orwell could have so understood the North Korean brand of totalitarianism" in his $1984 . .^{29}$ North Koreans may well often be deeply attached to their regime, but whatever success regime propaganda has is dependent on the complete absence of freedoms of movement and association which prevent them from escaping the regime's grip. ${ }^{30}$ No regime which was seriously constrained by public opinion could allow $10 \%$ of its population to starve to death whilst spending billions to keep around $20 \%$ of adult males under arms. In virtue of that, seeing North Korean citizens as responsible for their government's wrongs would add insult to the terrible injury of their complete subjugation.

Because North Korea is undoubtedly not a legal democratic state, its citizens cannot be held responsible for its wrongs on the grounds of having democratically authorized it. Some North Koreans - perhaps party members, who are implicated in its rule - may have some special responsibility to do something about their regime, but North Koreans in general do not. The problem is that this does not seem to be because North Korea is not democratic, as can be seen if look at another non-democratic state, Nazi Germany. The Nazi regime came to power in Germany in January 1933 as a result of manoeuvring amongst elites after a

\footnotetext{
28 The party's control over economic life collapsed as it became unable to feed the population, but the consequence of this seems to have been that economic life, beyond subsistence farming and the sale of food, more or less ceased altogether. See the accounts collected in Barbara Demick (2010) Nothing to Envy (London: Granta). Demick quotes a defector claiming that unless direct party control over economic life had been relaxed, "there would have been a revolution" (pg. 157). Since economic activity beyond securing enough food to survive had ceased for most of the population, this, even if true, hardly constitutes a serious threat to the party elite's dominance. It also seems unlikely in a society where a couple who had been together for nearly a decade were so concerned about displays of ideological commitment that they did not reveal to each other their intentions to defect (see Nothing to Envy).

29 Nothing to Envy, pg. 283.

30 Nothing to Envy details the deep attachment many defectors felt to their regime. B. R. Myers' (2011) The Cleanest Race (New York: Melville House) argues North Korean ideology is misunderstood by many, and a more important part of the regime's underpinning than is widely assumed, not least because of the breakdown of barriers to information from abroad recently. However, Myers is unable to substantiate this second claim with data about the attitudes of ordinary North Koreans to their state, understandably given the difficulty of obtaining information from a police state like North Korea. His argument instead rests on analysis of domestic propaganda material. This does not show that the propaganda could succeed, if indeed it does, without extremely tight control over freedom of movement, association and the press coupled with draconian enforcement measures, which is what is important for my purposes.
} 
parliamentary election in November 1932 in which it had remained the most popular party. Once in power, it made use of existing institutions first to eliminate political opposition, then to reorganize German society on racist and eugenicist lines, before expanding territorially by absorbing Austria and part of Czechoslovakia, invading Poland, starting the Second World War, and murdering six million Jews in the Holocaust.

Despite the almost immediate removal of anything but a façade of democratic procedures once the Nazis came to power, the regime was popular and relied on the acceptance of the mass of the population at least well into World War Two. Though the costs of individual resistance were certainly high enough to make a mockery of the idea that citizens consented to the regime, most of the time the regime did not need to deploy force at all. This broad popular support was responsible for the ineffectiveness of what resistance there was. The regime could "rely upon a substantial level of popularity and an underlying consensus [on its authority] ... which it retained in all essentials until deep in the war".31 This meant "not only was resistance to Hitler carried out - inevitably, one might say - without active support from the mass of the people, but that even passive support was largely lacking for those risking everything to overthrow the system".32 This was because in "key areas" of policy, "Nazism blended into 'mainstream' national aspirations". ${ }^{33}$ This "massive popular readiness to embrace authoritarianism" in the aftermath of the difficulties of the Weimar Republic enabled the regime to isolate left-wing saboteurs, co-opt much of the military establishment, and retain the support of much of the Church-going public despite their often unsuccessful attacks on religious observances. ${ }^{34}$ The Nazi regime may have been able to do what it did without this underlying consensus on its right to rule, but without that consensus, the methods it would have had to use would have been considerably more constrained. That it was unable to remove crucifixes from schools yet turned Germany into a one-party state by purging its political opponents and inscribed a racial hierarchy that culminated in pogroms and extermination camps into its legal system is revealing about the means by which it

31 Ian Kershaw (2000), The Nazi Dictatorship: Problems and Perspectives of Interpretation (London: Bloomsbury), pg. 215, pg. 214.

32 The Nazi Dictatorship, pg. 214

33 The Nazi Dictatorship, pg. 211.

34 The Nazi Dictatorship, pg. 216. 
perpetuated its rule. ${ }^{35}$ Unlike North Korea, the regime did not rest on massive coercive force but on popular acceptance.

Because the Nazi regime is correctly understood to have this character, its citizens are widely understood to have been specially responsible for dealing with the aftermath of at least some of its crimes. ${ }^{36}$ Their cooperation and collaboration makes them responsible for what they cooperated and collaborated with. This is the same reason, it seems, that British citizens are responsible for the wrongs of their state. The political order in Nazi Germany relied on a general acceptance of its authority to achieve its ends, just as the political order in the United Kingdom does. If contemporary British citizens are responsible for their racist criminal justice system because their state is democratically authorized, this cannot be right. Nazi Germany was not democratically authorized, so its citizens cannot have been responsible in the same way that contemporary Britons are. Either the citizens of Nazi Germany had no special responsibilities to confront and redress its wrongs in virtue of their citizenship, or those responsibilities do not rest on having a relevantly similar relationship to their state as current citizens of the UK or the USA. If they have responsibilities for the same reason as Britons or Americans do, democratic authorization theory is wrong.

Consider then another case of the imposition of racial hierarchies, also often enforced by extra- or quasi-legal violence, the pre-Civil Rights era USA. The Jim Crow laws were the de jure codification and enforcement of a comprehensive racial hierarchy particularly in former confederate states, most often directed at blacks. The denial of political participation rights to and enforced segregation of non-whites disadvantaged them in all areas of life and left them systematically vulnerable to exploitation and domination by whites. In her presentation of democratic authorization theory, Stilz accepts that that regime was a democratic legal state for at least its white members, and so treats them as specially

\footnotetext{
35 See The Nazi Dictatorship, pg. 193, for a list of some acts of petty refusal and dissent in the Third Reich, catalogued under the auspices of 'The Bavaria Project' at The Institute of Contemporary History in Munich.

36 There is clearly a point at which German citizens at large ceased to be responsible for what the Nazi regime did as it began to breakdown under the pressure of the defeats which eventually destroyed it. Orders given from Hitler's bunker in Berlin in days before his suicide are not something the German citizenry can be held responsible for the consequences of. The Nazi state had ceased to provide a political order which was not nakedly coercive for those remaining under its command by that point. When exactly this happened is almost certainly different for different (geographical and policy) areas of the regime.
} 
responsible for it, while denying that citizens of Nazi Germany are. ${ }^{37}$ This is despite both regimes relying on citizens' willed acceptance to continue. Neither was sustained directly by the state's brute force, though of course violence was relevant, but instead rested on the willingness of at least a majority of citizens not to actively oppose it. Neither were societies where government control was as total is it is in contemporary North Korea, for example. The hierarchies they created both depended on citizens accepting the state's right to rule, and would have been of a quite different character if they had needed to be imposed through coercion alone.

Yet, despite their often at best craven attitude towards racist domination and violence, the USA's democratic institutions are supposed to make the crucial difference for citizens' responsibilities. This seems implausible. What appears to matter is not the institutional structure, but the relation of the institutions to the popular will. If the popular will acquiesces in those institutions, then it and its members are implicated in their crimes. Because citizens are implicated in the state's crimes, they are remedially responsible for them and so can be required to bear the costs of putting them right. ${ }^{38}$ Democratic authorization theory faces a burden of explanation. We judge citizens of Nazi Germany as responsible for their regime's crimes for much the same reason as we judge citizens of the pre-civil rights era USA responsible for those of theirs. Democratic authorization theory denies that this is the case, and so disagrees with what seems one of considered judgments we ought to begin our theorising about political morality from. Of course we may come to the conclusion those judgments are false, but we need an explanation of why. Democratic authorization theory is weakened by the way it ignores the apparently central reliance on popular support when it distinguishes citizens' responsibility for racial hierarchies in Nazi Germany and the postbellum USA.

Democratic authorization theory has another problem. As well as denying that regimes can be accountable to their citizens without being democratic, it holds citizens responsible for all the wrongs of democratic states connected with the protection of their basic rights. This means citizens of democratic states can be responsible for wrongs committed by their states

\footnotetext{
37 Collective Responsibility and the State, pg. 204.

38 Another way of putting this point would be to say that in order to 'make sense' to their population and so fulfil Bernard Williams' 'Basic Legitimation Demand', states do not have to be democratic, as indeed Williams understood (see his Realism and Moralism in Political Theory).
} 
or their states' agents even when they knew nothing of them or the bodies that committed them. For example, consider the rule of Dame Shirley Porter over Westminster City Council in the $1980 \mathrm{~s}^{39}$ Porter gerrymandered Westminster to ensure that her party, the Conservatives, retained control over it by manipulating the Council's housing stock. Crucially, she was able to do so because she had undermined the structures of governance which made the Council transparent and accountable. By the end of her reign, the programme of gerrymandering, known as Building Safer Communities (BSC), had become "an industry within City Hall requiring its own separate and secret administrative structure which bypassed and eventually consumed the City Council".40 Senior Council officers "took their orders directly from the BSC infrastructure and the Chairmen's Group [run by Porter] in particular" rather than the councillors as a whole. ${ }^{41}$ Porter moved Conservative voters into key marginal wards by selling council houses in them, and so replacing poorer renters with wealthier owner-occupiers. The evicted renters were moved into unsafe housing or to other boroughs far from work and support networks, and even denied housing altogether. By the end, the loss to the Council, never mind to the people left homeless or inadequately housed, was over $£ 40$ million, a loss British courts judged Porter and her co-conspirators personally liable for.

Democratic authorization theory treats Porter's corruption as something that British citizens in general are responsible for. The UK was, presumably, a legal democratic state in the 1980s. Schemes for providing housing for the homeless are surely part of the provision of a political order, and so authorized by the citizenry at large in such a state according to democratic authorization theory. ${ }^{42}$ Yet Porter deliberately disguised what she was doing, and was judged to be personally liable for some of its costs by the same institutions whose

\footnotetext{
39 I draw my account of Porter's misdeeds from Andrew Hosken (2006), Nothing Like A Dame, (London: Granta).

40 Nothing Like A Dame, pg. 194

41 Nothing Like A Dame, pg. 195.

42 Uses of the rights associated with the provision of a political order do not have to be appropriate to be authorized and so something citizens can be responsible for on the democratic authorization view. As Stilz puts it, the "authorization view stipulates that if a state qualifies as authorized, citizens will have reason to act on its judgments - not their own - as to the exercise of their rights" (Collective Responsibility and the State, pg. 201). Unless this was the case, Stilz would not be able to hold that British and American citizens are responsible for the invasion and occupation of Iraq in 2003 (Collective Responsibility, pp. 205-208). Consequently, since local authorities may sell council housing and evict renters for a variety of reasons, Porter's behaviour does not fall outside the authorization supposedly given to the state by citizens. She was not like a guardian gambling away their ward's inheritance (Collective Responsibility, pg. 201).
} 
rules she had breached. ${ }^{43}$ This was not a case where institutions had a formal set of rules which it was widely recognised did not actually govern them, as we might say when bribery is illegal but it is impossible for civil servants to survive on their salaries alone. In such a case, we might think that since the citizenry acquiesce in the real rules of the institution, they are partly responsible for them. Porter's wrongs, though, cannot be described as having been acquiesced in by the citizenry at large since it was not and could not have been clear until well after the fact what she had done. ${ }^{44}$ Democratic authorization theory does not just draw what seems like an irrelevant distinction between democratic legal states and other states which also rely on popular acquiescence in their claim to a right to rule. It also fails to exclude cases where citizens as such have no involvement in the wrong in question at all because of its secrecy. This is not a minor issue. Consider questions about responsibility for paramilitary activity backed by elements of the state security apparatus. Were Spanish citizens in general responsible for the campaign of kidnapping and assassination of suspected members of the terrorist Basque separatist group, Euskadi Ta Askatasuna (ETA) by the Grupos Antiterroristas de Liberación (GAL) in the early 1980s in Spain? Government ministers were certainly involved, but it is not clear who knew what and when, and to what extent the campaign should be seen as part of a broader attempt to brutalise Basque separatists. ${ }^{45}$ The question does not make even sense for democratic authorization theory, though, because it lacks a distinction between clandestine and public state acts.

The four cases I have discussed here suggest that we need at least two criteria when considering whether a state's citizens are responsible for wrongs it commits. First, they suggest the importance of a criterion to judge whether citizens generally accepted the state's claim to a right to rule. This effectively replaces the criterion of being a legal democratic state in Stilz's democratic authorization theory. Without that replacement, we

\footnotetext{
43 Porter's civil liability for the costs of her policy to Westminster seems unlikely to be grounds for denying that it was part of the authoritative provision of an order to British citizens, and so something they were responsible for according to democratic authorization theory. The citizens it most directly affected were not compensated, and quasi-legal measures can clearly be part of such an order, as both the Nazi and Jim Crow regimes illustrate.

${ }^{44}$ British citizens were of course responsible for the general shape of housing policy under Thatcher, which gave Porter the opportunity to gerrymander Westminster. That is not the same as being responsible for Porter gerrymandering Westminster.

45 See Paddy Woodworth (2001), Clean Hands, Dirty War (Cork: Cork University Press) for a history of GAL's operations and the involvement of the democratic Spanish government in its campaign of kidnap and assassination.
} 
will have to implausibly distinguish between citizens living in states which were popularly accepted despite being non-democratic and those in liberal democratic states, even though in both cases citizens provide the state with the means it uses to commit its injustices.

Second, it seems that as well as a distinction between types of political system, we need one between types of wrongdoing. We must supplement the focus on the form of the state by excluding wrongs which citizens were not involved in, because of their scope or secrecy. Otherwise, we will have to judge citizens as responsible for wrongs like Dame Shirley Porter's gerrymandering as for the pre-civil rights era marginalization of non-whites in the United States.

\section{Participation, Breadth and Joint Authorship}

Perhaps this is too quick though. Any theory worth having is likely end up forcing us to discard some of the judgments we made beforehand, since we often look to theories to resolve conflicts between our existing judgments. We need more than some unfortunate implications to show we should abandon a theory. We need, at a minimum, a diagnosis of what has gone wrong and what we would need to do in order to avoid making the same mistakes - or indeed different ones. Clearly, given the problem with accounts of citizens' responsibility based on benefit or endorsement, any successful account of citizens' responsibility will have to be sensitive to citizenship's political character. The four historical cases suggest that such an account will also have to distinguish between regimes that rest on the acceptance of their right to rule and those that do not, and between wrongs that are relevantly public and those that are carried out in secret. The importance of providing political order explains the need to avoid relying on claims about benefit or endorsement; what we need now is an explanation of why and how distinctions between accepted and nakedly coercive regimes, and between public and private wrongs, are also necessary.

We can begin with democratic authorization's problems. Although some of its difficulties undoubtedly rest with the content of its notion of authorized states, its weakness seems to be deeper that than. Authorization itself is problematic. Typically, we authorize another to act on our behalf consensually. If I have no choice about who defends me in court or how they do so, then we do not think of what they provide as my defence precisely because I have not authorised them to provide one for me. Yet, given its coercive power, citizens are in no 
position to consent to their state's authority. ${ }^{46}$ Stilz even claims that citizens stand in a similar relationship to the state as a child does to those holding its property in trust. ${ }^{47}$ Fiduciary relationships of that sort do not seem to involve authorization though. A child's property is held in trust because the child is not in a position to authorize uses or users of it. If they could, then it would not need to be held in trust. Since citizens typically lack the opportunity to reject the state, authorization seems unlikely to be a helpful way to think about their relation to it.

Authorization is certainly not the only way we can become partly responsible for another's wrong. We do not have to have authorized another to do something on our behalf in order to feel that various reactive attitudes are warranted towards our conduct. I might include you in a confidence, explicitly telling you not to pass it on. Yet, when you do let the secret out, I and others might reflect on your deserved reputation for spreading gossip and think that I should have known better. I made sure to forbid you from breaking the confidence, but it is quite reasonable for me to feel guilty and for others to blame me for helping you to do so. What matters is that I played a role in the series of events that culminated in the wrongdoing of the secret being let out. Authorization is neither here nor there.

This seems to be the idea that gives us reasons for distinguishing between popularly accepted and nakedly coercive regimes, and between public and secret wrongs. What matters is the complicity of citizens in the wrongs that they can be held partly responsible for. Their agency is somehow implicated in the commission of those wrongs. When a totalitarian dictatorship like North Korea commits wrongs, the way it behaves does not really engage the wills of its citizens as purposive agents, forming and acting on goals of their own. It directs or destroys its citizens' wills as it pleases. It treats them as tools, or objects to be manipulated, which at best impose merely physical limits on what can be done with them. While a torturer might capture the will of their victim by breaking it, such regimes might be usefully described as substituting theirs for their citizens' by preventing them from forming one in the first place. Citizens who lack that capacity for independent action can hardly be said to have involved themselves in the state's wrongdoing. They are no more capable of involving themselves in the acts of the massive coercive apparatus that

\footnotetext{
46 It has been standard to hold that citizens cannot consent to their state at least since A. J. Simmons' (1979) Moral Principles and Political Obligations, Princeton: Princeton University Press.

47 See Collective Responsibility and the State, pg. 201.
} 
controls them than marionettes are in those of their puppeteers. Unlike the citizens of a state that operates through its citizens' acceptance of its right to rule, their agency is not implicated in any wrongs their state commits.

Similarly, when a state commits a wrong secretly, it does not depend on citizens' acceptance of a right to rule. It conceals what is being done with resources supplied by those citizens and so does not implicate their agency because their cooperation is not needed. The ability to commit wrongs like Dame Shirley Porter's gerrymandering may depend on citizens' acceptance of a state's right to rule, but only in the same sense that leaving my flat to go to work makes it possible for a burglar to break in and steal my stereo. That kind of dependence does not warrant a sharing or transfer of responsibility. The relation is best described as one of exploitation or manipulation, and so does not engage the will of other agents it relies on. Since they are used rather than involved, it appears unreasonable to expect them to bear any special responsibility another's wrongdoing.

Participation is the key concept here. It is because agents play a role, are participants, in another's wrongdoing that we can attribute some responsibility to them for that wrongdoing. As Christopher Kutz has argued at length, participation does not require consenting to or endorsing, or making a causal difference, yet it is enough to make an agent complicit in the wrongdoing of another, whether that other is an individual or collective agent.48 When an agent acts as part of a collective, because of the way that what they are doing is mutually dependent on what other members of the collective do, there is a sense in which the acts of the collective can be attributed to them. Although they cannot have the acts of the collective exclusively attributed to them, as having written this paper can be exclusively attributed to me, those acts can be inclusively attributed to them, and that is enough for some responsibility. ${ }^{49}$ What Kutz has in mind here is the sense in which I can have had a vicious fight or danced a lovely tango, even though in both cases someone else needed to be involved since it is impossible for me to have done those things alone. I danced a lovely tango or had a vicious fight only because we danced a lovely tango or had a vicious

\footnotetext{
48 See his (2000) Complicity, Cambridge: Cambridge University Press.

49 See the discussion in Complicity, pp. 139-141. Although Kutz says there that the difference is that exclusive attributions "presuppose" causality, he elsewhere argues that giving an account of causation absent a rich and normative account of agency is impossible. See Complicity, pp. 40-42 and 51-52. Hence the difference is one of degree, not of kind.
} 
fight, and I may be proud of our tango or ashamed of our fight only because of what we have done. Reactive attitudes towards me become appropriate because of my participation in our collective acts.

Participation in this sense does not depend on control over its consequences or making a difference to what happens more generally. Consider Bernard Williams' example of George the chemist.50 George is unemployed and frail, and offered work in a chemical and biological weapons laboratory. If he does not accept the work, a more ambitious contemporary will and so make the laboratory more effective than George would. It is consequentially worse, even for George given his situation, for him to refuse the offer. Yet, even though George only reduces the danger of the laboratory's work and has no input into the military's decisions about how to use it, we feel that he is in some way implicated in what it does and so responsible for involving himself in it.

Indeed, Williams' use of the case to illustrate the importance of integrity as a virtue depends on George's implication in what the laboratory does. This is presumably because of the way what he does in the laboratory is structured around serving his funder's project of producing biological and chemical weapons. As Kutz puts it when discussing a similar case, such work is morally problematic because it "is counterfactually sensitive to the promotion of [his funder's] goals and the observance of their constraints".51 Because of that, as a purposive agent, George can in some sense be held responsible for what the military does with the work he produces. By promoting their goals and observing their constraints, he plays a role within the project and so we can inclusively attribute their acts to him. Notice that no act of authorization or consent need have occurred. George may continually refuse to grant his superiors permission to use his work in the way they do, yet as long as he continues to do his work, he continues to be governed by their plans. ${ }^{52}$

\footnotetext{
50 Bernard Williams (1988), 'Consequentialism and Integrity', in Consequentialism and its Critics, pp. 20-50, ed. Samuel Scheffler, Oxford: Oxford University Press, pp. 33-4.

51 Complicity, pg. 164. Here, Kutz is discussing the case of a scientist, Miriam, who works for the military. I use Williams' case instead because it predates Kutz's work and so emphasises how common thinking in the way he suggests we do is, and because the case more clearly shows that making a causal difference to and controlling what we are responsible for are not always relevant. 52 This is sufficient to show that George does not necessarily consent. We do not consent to something simply by being aware that it will happen if we continue some course of action.
} 
To see whether an agent is a participant in some collective wrong then, we need to know what the goals and constraints of the agent committing the wrong are and whether the possibly complicit agent is promoting and observing them. There has to be a sense in which we can attribute the aims of the collective to a participant in its act through what Kutz calls a participatory intention. 53 Two things seem to need to be true to warrant calling some agent a participant in another's wrong. First, there needs to be a project broad enough to encompass what both of them did. George the chemist could be contrasted with Georgina, whose work on the spread of disease through a population just happens to be useful to chemical and biological weapons manufacturers. Her work may be more helpful to the military than George's, whose frailty and scruples may limit his effectiveness. Yet she is not involved in or responsible for their wrongdoing in the same way. ${ }^{54}$ She is not a participant in their project, because her acts are not structured by their constraints and so there is no project they share. Call this the breadth criterion. ${ }^{55}$ Second, the participant needs to have acted to further the ends of that project, to have not merely been a tool of it. Contrast George with Geoff, one of the convicts being used as a test subject for the new strains of disease George is developing. Geoff does not cooperate with the military. He is dragged from his cell, restrained while being exposed to the infective agents and, when he receives treatment to help him recover from their effects, does so whether or not it furthers the military's ends. He is used by their project instead of participating in it and is in no way responsible for it. Call this the joint authorship criterion.

\footnotetext{
53 See Complicity, pp. 66-112. Kutz defines a participatory intention as "an intention to do my part of a collective act, where my part is defined as the task I ought to perform if we are to be successful in realizing a shared goal" (pg. 81). My breadth and joint authorship conditions roughly fill in for what Kutz calls the "individual role" and "collective end" (pg. 81).

${ }^{54}$ She may of course be negligent in her failure to protect their victims, but that is a different wrong from the one George commits or is involved in. Her case demonstrates that Chiara Lepora and Robert E. Goodin's criterion for complicity, of foreseeable causal contribution, is too inclusive. Georgina is not complicit in the military's development and use of chemical weapons simply because she did work which she could have seen would contribute to that development and use. This is independent of Lepora and Goodin's failure to understand what Kutz means by 'intention', reading it much more narrowly than he does. See Lepora and Goodin (2013) On Complicity and Compromise (Oxford: Oxford University Press), particularly pp. 80-81.

55 The failure to meet the breadth criterion makes me sceptical about Kutz's attempt to apply his model to what he calls 'unstructured harms' (see Complicity, pp. 166-203). It seems to me that the harms he discusses there are not ones where people can really be seen as playing a role in a collective project because their intentions are not structured by any such project.
} 
We then have two criteria, the breadth criteria and the joint authorship criteria. We participate in a collective project if our intentions are structured by its goals and constraints. The joint authorship criterion responds to the importance of our intentions, while the breadth criterion responds to the importance of the project's goals and constraints. Again, let me reiterate that this is different from consent or authorization. We can intend to do things we did not consent to doing, just as intentions can be sensitive to a project's goals and constraints without having authorized that project. I intend to pay my taxes when I send back my self-assessment form, though I have not consented to, just as that intention is structured by the goals and constraints of the project of tax collection whether or not I authorize it. Nor will all instances of consent or authorization be participatory. I may consent to and authorize an operation under anaesthesia, but do not participate in it.

Notice the similarity between the two criteria for participation in general, of breadth and joint authorship, and the two criteria I claimed earlier were needed by a successful account of when citizens are responsible for their state's wrongdoing. The distinction between wrongs that are carried out in secret and those that are carried out publicly is an instance of the breadth criterion. Equally, distinguishing states that are nakedly coercive and those that are generally accepted is one way of distinguishing between those that involve their citizens as joint authors and those that do not. That the two criteria for citizens' responsibility can be related to the two criteria for participation, of course, does not show that they are the right way to think about citizens' responsibility for state wrongs. What it does do is show that as criteria they can be linked to the framework of participation. That means there is an explanation of not just where the democratic authorization account went wrong, but how to correct its errors. If there are reasons to generally think about our involvement in the wrongs of others in terms of participation, then there are reasons to think about citizens' involvement in their states' wrongs in particular in those terms. That, the joint authorship and breadth criteria imply, means drawing distinctions of the sort I have argued the democratic authorization account struggles with.

An account of citizens' responsibility for state wrongs built around the idea of participation would, then, explain and correct the problems of using the idea of authorization to justify citizens having to remedy their state's wrongdoing. Even if that means we should give up on the idea of authorization, it does not mean that participation must be the answer to why and when citizens are responsible for their state's wrongdoing. Showing that would mean 
showing that there are no problems with using participation as the basis of an account of citizens' responsibility, and I clearly have not done that. However, if participation is a better framework for explaining when citizens are responsible than at least one prominent alternative, we at least have reason to explore it. We need to check whether a theory built around the idea of participation can be made to fit well with a range of judgments about citizens' responsibility beyond those I have pointed to in this paper. By way of conclusion, let me suggest how that search might begin.

The two criteria of breadth and joint authorship must be interpreted for the case of citizenship. In order to know whether a citizen is a participant in their state, we need to understand what the project the state should be seen as engaged in is and how to judge whether it is using its citizens as mere tools to pursue it. In discussing accounts of citizens' responsibility based on endorsement and benefit in the first section of the paper, I suggested that any account of citizens' responsibility would need to be sensitive to the kind of activity that politics is. It involves providing ourselves with an order that makes it possible for us to pursue our different ends in relative peace with one another, including through arrangements we make with each other. I claimed that because of that it cannot be done consensually or on the basis of shared ends, and lacks a baseline that we could assess its benefits from. This is why consent, endorsement and benefit are inappropriate criteria for assessing citizens' responsibility for their involvement in it. These considerations also bear on the question of citizens' participation in their state. If what political authorities do is provide an order for their members, then understanding the limits of that objective will be the focus of interpreting the breadth criterion there. We need to know what counts as part of that task. This will help us resolve questions like those about GAL's campaign against suspected ETA members.

Equally, when citizens are joint authors of that order will depend on our characterization of their agency. If we think of citizens as the kind of agents who become joint authors by consent, then we will find very few, if any, citizens who participate in their state's provision of an order to them. Some more minimal criterion seems necessary, yet that criterion will itself have to be justified. Consent is a plausible mechanism for creating and transferring normative powers because of the respect it shows for the capacity of purposive agents to direct their own lives. In the absence of a political order though, it may well be systematically unavailable. Instead, we will have to look for some other form of respect for 
purposive agents and their powers. Without that, we will not be able to reliably sort between cases of authoritarian states like Nazi Germany which rely on popular acquiescence and those like North Korea which are nakedly coercive. Participation needs to develop more fully its equivalent to democratic authorization's criterion of a democratic legal state.

Robert Jubb, Leverhulme Early Career Fellow, Department of Politics and International Relations, University of Leicester. rj138@le.ac.uk. 